\title{
Predictive value of umbilical cord blood bilirubin and albumin for significant hyperbilirubinemia in ABO incompatibility
}

\author{
Janaki A. N. ${ }^{1}$, Selvakumar P. ${ }^{2}$ \\ ${ }^{1}$ Dr. Janaki A. N, Junior Resident, ${ }^{2}$ Dr. Selvakumar P, Associate Professor. Both authors are affiliated to Department of \\ Pediatrics, Thanjavur Medical College, Thanjavur, Tamil Nadu, India. \\ Corresponding Author: Dr. Selvakumar P., 180, $9^{\text {th }}$ Cross, Arulananda Nagar, Extension, Thanjavur -1 . \\ E-mail: drselva_kumar69@yahoo.co.in
}

\begin{abstract}
Introduction: ABO incompatibility is the most common cause of hemolytic disease of the newborn with approximately $15 \%$ of live births at risk. The objective of this study wasto estimate the levels of bilirubin and albumin in cord blood and determine their relationship with the occurrence of neonatal hyperbilirubinemia in ABO incompatibility. Methods: Design: Prospective study. Study settings: Raja Mirasudhar Hospital, Thanjavur. Participants: Healthy term neonates (n92) born to O+ve mothers. Control: neonates (n-55) with blood group O+ve. Case: neonates (n-37) with blood group A+ve or B+ve. Procedure: Umbilical cord blood was collected from newborns and serum albumin and bilirubin levels estimated. The babies were followed-up daily for development of jaundice and serum bilirubin was measured in all newborns at 24 and 72 hours of life. Result: The mean serum total bilirubin and albumin in umbilical cord blood were $1.596+0.46 \mathrm{mg} / \mathrm{dland} 3.587+.65 \mathrm{~g} / \mathrm{dl}$ in control group and $1.995+1.16 \mathrm{mg} / \mathrm{dl}$ and $3.559+.64 \mathrm{~g} / \mathrm{dl}$ in case group respectively. Umbilical cord serum albumin level of $<3.15 \mathrm{~g} / \mathrm{dl}$ predicts the development of significant hyperbilirubinemia with a sensitivity of $76.5 \%$, specificity of $78.7 \%$ and an accuracy of $77.6 \%$. Umbilical cord serum total bilirubin of $>1.85 \mathrm{mg} / \mathrm{dl}$ predicts the development of significant hyperbilirubinemia with a sensitivity of $70.6 \%$, specificity of $82.7 \%$ and an accuracy of $76.7 \%$. Conclusion: In ABO blood group incompatibility, neonates with umbilical cord blood total bilirubin $>1.85 \mathrm{mg} / \mathrm{dl}$ and albumin $<3.15 \mathrm{~g} / \mathrm{dl}$ need close follow up to watch for development of significant hyperbilirubinemia while those babies with umbilical cord total bilirubin $<1.85 \mathrm{mg} / \mathrm{dl}$ and albumin $>3.15$ $\mathrm{g} / \mathrm{dl}$ can be safely discharged early.
\end{abstract}

Key words: Bilirubin, Cord blood, Neonatal hyperbilirubinemia, Serum albumin.

\section{Introduction}

ABO incompatibility occurs in about $15 \%$ of pregnancies. Only $<1 \%$ of these babies develop significant hyper bilirubinemia requiring treatment. Very high bilirubin levels and kernicterus have occurred in $\mathrm{ABO}$ incompatible healthy term newborns with unrecognized hemolysis and negative Direct Antibody Test [1]. Kernicterus has been enlisted as one of the Never Events in the United Kingdom by National Institute of Health and Clinical Excellence (NICE) and inthe United States by National Quality Forums [2].

Early postnatal discharge of healthy term newborns within 48 hours of life has become common nowadays. This reduction in hospital stay allows the family to

Manuscript received: $6^{\text {th }}$ January 2018

Reviewed: $16^{\text {th }}$ January 2018

Author Corrected: $25^{\text {th }}$ January 2018

Accepted for Publication: $31^{\text {st }}$ January 2018 return to their daily routine at the earliest and reduces the economic burden on them in a developing country like India. However, neonatal jaundice, the commonest cause for readmission of newborns to hospital goes unnoticed in those discharged early $[3,4]$. American Academy of Pediatrics mandates a follow-up visit after 48 to 72 hours of discharge for all neonates who were discharged before 48 hours of life to look for any significant jaundice and other problems [5]. But such follow-up is not feasible in all cases in our country due to parental noncompliance and ignorance.

Though our understanding of neonatal hyperbilirubinemia has improved in the recent years, we are still not able to precisely predict those babies at risk of developing significant hyperbilirubinemia. Many researchers studied the correlation between the umbilical cord blood bilirubin and albumin in predicting 
Editorial

significant neonatal hyper bilirubinemia [6-8]. However no study has established a single cut off value for umbilical cord serum bilirubin and albumin especially in $\mathrm{ABO}$ incompatibility to allow us to predict at birth those babies who will develop significant hyperbilirubinemia to require therapeutic intervention.

Thus the present study was conducted to evaluate the predictive ability of the umbilical cord blood bilirubin and albumin for significant neonatal hyperbilirubinemia in $\mathrm{ABO}$ incompatibility.

\section{Methodology}

Period of study: February 2017 to August 2017

Place of study: Raja Mirasudar Hospital attached to Thanjavur Medical College, Thanjavur.

Study design: Prospective study

Sampling method: Purposive sampling

Sample size: Sample size was calculated using online openepi.com. Keeping the two sided confidence interval as $99 \%(\alpha=0.99)$ and power as $90 \%(\beta=0.9)$, the ratio between the groups as 1 and the mean difference between the group as 0.37 with standard deviation of 0.46 the sample size obtained was 92 . Keeping $10 \%$ dropout $(10 \%$ of $92=\sim 9)$ the final sample size was 100 for two groups.

Inclusion criteria: Term babies ( $>37$ completed weeks) of both gender delivered at Rajah Mirasudhar Hospital attached to Thanjavur Medical College, Thanjavur, bynormal vaginal delivery / cesarean section with a birth weight of 2.5 to $4 \mathrm{~kg}$ and an Apgar score of 7 or more at 1 minute. The case group comprised of babies with blood group $\mathrm{A}$ or $\mathrm{B}$ positive born to $\mathrm{O}$ positive mothers while the control group comprised of babies with blood group $\mathrm{O}$ positive born to $\mathrm{O}$ positive mothers.

Exclusion criteria: Neonates, who were preterm, asphyxiated, had associated congenital anomalies, born to diabetic mother, delivered by instrumental delivery (vacuum/forceps), history of meconium stained amniotic fluid or at risk of sepsis (premature rupture of membranes $>12$ hours)

The study was approved by the institutional ethics committee. Informed written consent was obtained from the parents. A detailed history including mother's age, maternal complications, medications, family history of neonatal jaundice and type of delivery was obtained by interviewing the mother and from maternal hospital records. A complete physical examination of the baby was done at birth to assess the gestational age, and to look for the presence of birth trauma, congenital anomalies and cephalhematoma. Apgar score at $1^{\text {st }}$ and $5^{\text {th }}$ minute of life was recorded. About $3 \mathrm{ml}$ of cord blood was collected at birth for blood grouping, Rh typing and estimation of serum bilirubin and albumin.

The babies were examined daily and looked for the development of jaundice. Serum bilirubin was estimated in all newborns at 24 and 72 hours of life. Serum bilirubin was estimated by diazo method using Erba system pack reagent in auto-analyzer. Serum albumin was measured using Erba system pack reagent containing bromocresol green by biuret method.

Babies developing significant hyperbilirubinemia were treated with phototherapy and exchange transfusion as per American Academy of Pediatrics [AAP] 2004 guidelines [5]. Complete blood count, peripheral smear and direct coombs test were done in all babies who developed significant hyper- bilirubinemia.

The development of significant hyperbilirubinemia requiring phototherapy with or without exchange transfusion as per AAP guidelines was taken as the major outcome of the study.

The collected data were analysed with IBM.SPSS statistics software 23.0 Version. To describe about the data descriptive statistics, frequency analysis, percentage analysis were used for categorical variables and the mean \& S. D were used for continuous variables. To find the significant difference between the bivariate samples in independent groups the unpaired sample t-test was used.

The Receiver Operator Characteristic (ROC) curve analysis was used to find the cut-off with sensitivity and specificity for the efficacy of tools. To find the significance in categorical data, Chi-Square test was used. If the expected cell frequency is less than 5 in $2 \times 2$ tables, then the Fisher's Exact was used. In all the above statistical tools, the probability value of 0.05 is considered as significant level.

\section{Results}

During the study period, a total of 92 eligible neonates with 55 neonates in control group and 37 neonates in case group were enrolled in the study. The baseline demographic variables are shown in Table 1. 
Editorial

Table-1: Baseline characteristics of study population.

\begin{tabular}{|c|c|c|c|c|c|}
\hline S. No & Parameter & $\begin{array}{l}\text { Control } \\
(n=55)\end{array}$ & $\begin{array}{l}\text { Cases } \\
(n=37)\end{array}$ & $P$ value & Statistical test \\
\hline 1 & $\begin{array}{l}\text { Maternal Age } \\
\text { ( years) }\end{array}$ & $24.91 \pm 2.93$ & $26.03 \pm 2.98$ & $0.078(\mathrm{NS})$ & Unpaired ' $\mathrm{t}$ ' test \\
\hline \multirow[t]{3}{*}{2} & \multicolumn{5}{|c|}{ Sex of the baby } \\
\hline & Male & $25(45.5 \%)$ & $21(56.75 \%)$ & \multirow[t]{2}{*}{$0.395(\mathrm{NS})$} & \multirow[t]{2}{*}{ Fisher's exact test } \\
\hline & Female & $30(54.5 \%)$ & $16(43.25 \%)$ & & \\
\hline \multirow[t]{3}{*}{3} & \multicolumn{5}{|c|}{ Mode of the delivery } \\
\hline & Cesarean Section & $49(89.1 \%)$ & $35(94.6 \%)$ & \multirow[t]{2}{*}{$0.467(\mathrm{NS})$} & \multirow[t]{2}{*}{ Fisher's exact test } \\
\hline & Labor Natural & $6(10.9 \%)$ & $2(5.4 \%)$ & & \\
\hline 5 & $\begin{array}{l}\text { Birth weight of the } \\
\text { baby }(\mathrm{Kg})\end{array}$ & $2.9 \pm 0.31$ & $2.8 \pm 0.29$ & 0.517 (NS) & Unpaired ' $\mathrm{t}$ ' test \\
\hline 6 & Gestational age(days) & $274 \pm 6$ & $275 \pm 6$ & $0.195(\mathrm{NS})$ & Unpaired ' $\mathrm{t}$ ' test \\
\hline
\end{tabular}

$\mathrm{P}<0.05$ was considered statistically significant. NS=Nonsignificant

Data were expressed as mean \pm SD except sex of the baby and mode of delivery wherein the data are expressed as absolute numbers with percentages. There were no differences between the groups in all parameters.

The mean serum total bilirubin and albumin in umbilical cord blood were $1.596+0.46 \mathrm{mg} / \mathrm{dland} 3.587+.65 \mathrm{~g} / \mathrm{dl}$ in control group and $1.995+1.16 \mathrm{mg} / \mathrm{dl}$ and $3.559+.64 \mathrm{~g} / \mathrm{dl}$ in case group respectively. Table 2 shows the comparison between cases and control of umbilical cord blood albumin and bilirubin and bilirubin at 24 and 72 hours.

Table-2: Comparison of albumin and bilirubin levels in cord blood and bilirubin at 24 and 72 hours of life between the control and case groups.

\begin{tabular}{|c|c|c|c|c|c|c|}
\hline & & & & & Std. Error & \\
\hline & & $\mathbf{N}$ & Mean & Std. Deviation & Mean & $P$ value \\
\hline \multirow[t]{2}{*}{ Cord Sr. ${ }^{*}$ Albumin } & Control & 55 & 3.587 & .6569 & .0886 & .842 \\
\hline & Cases & 37 & 3.559 & .6496 & .1068 & .842 \\
\hline \multirow{2}{*}{$\begin{array}{c}\text { Cord Total Sr.* } \\
\text { Bilirubin }\end{array}$} & Control & 55 & 1.596 & .4670 & .0630 & .025 \\
\hline & Cases & 37 & 1.995 & 1.1638 & .1913 & .054 \\
\hline \multirow{2}{*}{$\begin{array}{l}\text { Cord Indirect Sr.* } \\
\text { Bilirubin }\end{array}$} & Control & 55 & 1.391 & .3831 & .0517 & .054 \\
\hline & Cases & 37 & 1.697 & 1.0707 & .1760 & .102 \\
\hline \multirow{2}{*}{$\begin{array}{c}\text { Total Sr. }{ }^{*} \text { Bilirubin at } \\
24 \text { hours of life }\end{array}$} & Control & 55 & 7.571 & 3.3235 & .4481 & .406 \\
\hline & Cases & 37 & 7.035 & 2.4940 & .4100 & .380 \\
\hline \multirow{2}{*}{$\begin{array}{l}\text { Indirect Sr.*Bilirubin } \\
\text { at } 24 \text { hours of life }\end{array}$} & Control & 55 & 6.773 & 3.4620 & .4668 & .311 \\
\hline & Cases & 37 & 6.105 & 2.4031 & .3951 & .278 \\
\hline \multirow{2}{*}{$\begin{array}{c}\text { Total Sr.*Bilirubin at } \\
72 \text { hours of life }\end{array}$} & Control & 55 & 12.384 & 3.0205 & .4073 & .069 \\
\hline & Cases & 37 & 13.686 & 3.7483 & .6162 & .082 \\
\hline \multirow{2}{*}{$\begin{array}{l}\text { Indirect Sr.*Bilirubin } \\
\text { at } 72 \text { hours of life }\end{array}$} & Control & 55 & 11.013 & 2.6942 & .3633 & .152 \\
\hline & Cases & 37 & 11.957 & 3.5662 & .5863 & .176 \\
\hline
\end{tabular}

*- Serum 
The umbilical cord blood total bilirubin was significantly higher in babies with ABO incompatibility than the control group. There was no statistically significant difference in other parameters between the groups.

A total of 9 neonates in control group and 8 neonates in case group developed significant neonatal hyperbilirubinemia requiring phototherapy. 2 babies in case group required exchange transfusion while none in control group required exchange transfusion.

Table-3: Comparison of incidence of significant neonatal hyperbilirubinemia between the case and control group.

\begin{tabular}{|c|c|c|c|c|c|}
\hline & & & Control & Cases & Total \\
\hline \multicolumn{2}{|c|}{ JAUNDICEAbsent } & Count & 46 & 29 & 75 \\
\hline & & $\%$ & $83.6 \%$ & $78.4 \%$ & $81.5 \%$ \\
\hline & Present & Count & 9 & 8 & 17 \\
\hline & & $\%$ & $16.4 \%$ & $21.6 \%$ & $18.5 \%$ \\
\hline \multicolumn{2}{|c|}{ Total } & Count & 55 & 37 & 92 \\
\hline \multicolumn{2}{|l|}{} & $\%$ & $100.0 \%$ & $100.0 \%$ & $100.0 \%$ \\
\hline
\end{tabular}

There is no statistically significant difference in incidence of neonatal hyperbilirubinemia between case and control group with a $\mathrm{p}$ value of 0.524 which is higher than 0.05 .

Figure1 shows the Receiver Operator Characteristic curve showing the area under the curve for the predictive ability of umbilical cord serum albumin for significant hyperbilirubinemiain the case group.

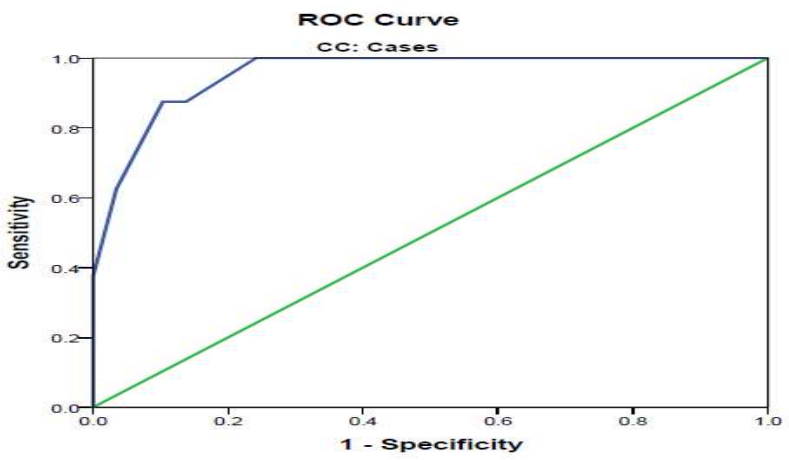

Figure-1: Area under the curve for umbilical cord serum albumin

Umbilical cord albumin level of $3.15 \mathrm{~g} / \mathrm{dl}$ has a large area under the curve of 0.955 indicating its high predictive ability for significant hyperbilirubinemia.

The Figure 2 shows the area under the curve for the predictive ability of the umbilical cord serum total bilirubin for the development of significant hyperbilirubinemiain case group.

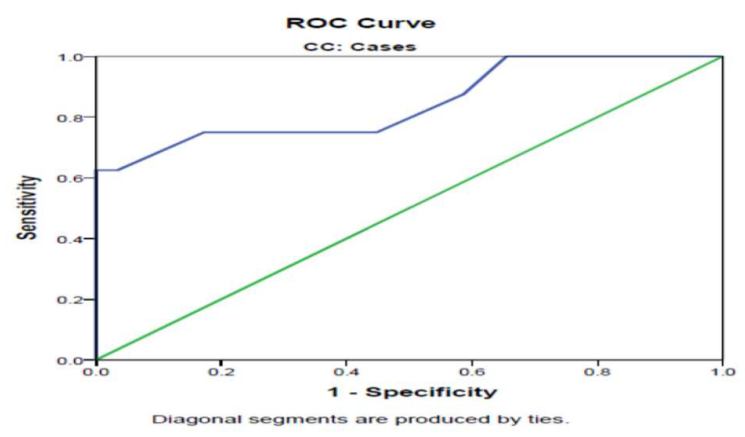

Figure-2: Area under the curve for umbilical cord serum bilirubin 
The umbilical cord total bilirubin level of $1.65 \mathrm{mg} / \mathrm{dl}$ has an area under the curve of .845 for predicting significant hyperbilirubinemia in the case group.

\section{Discussion}

Overall, 100 neonates who fulfilled the inclusion and exclusion criteria were enrolled in the study. Of them, 4 neonates who could not be followed up and 3 neonates who got admitted in the NICU for sepsis, neonatal seizures and respiratory distress were excluded from the study. Another baby, who on evaluation was found to have conjugated hyperbilirubinemia was also excluded from the study. The dropout rate was $8 \%$ and the remaining 92 neonates were followed up. 55 neonates with blood group $\mathrm{O}+\mathrm{ve}$ served as controls and 37 babies with blood group $\mathrm{A}+\mathrm{ve}$ and $\mathrm{B}+\mathrm{ve}$ served as cases. There was no statistically significant difference in the baseline demographic characteristics between the 2 groups.

The mean serum albumin level in the umbilical cord blood was $3.587+0.65 \mathrm{~g} / \mathrm{dl}$ in control and 3.559+0.64 g/dl in case group. There was no statistically significant difference in mean serum albumin level in umbilical cord blood between the two groups.

The mean cord serum total bilirubin level was $1.995+1.16 \mathrm{mg} / \mathrm{dl}$ in cases, which was significantly higher than $1.596+.46$ $\mathrm{mg} / \mathrm{dl}$ in control group. This result was similar to Zietounet al. [6] Aljabri et al [7] and Hamdi et al [8] studies. There was no statistically significant difference in mean serum bilirubin between the groups at 24 and 72 hours of life. The mean serum total bilirubin at 24 hours of life was $7.571+3.32 \mathrm{mg} / \mathrm{dl}$ in control group and $7.035+2.49 \mathrm{mg} / \mathrm{dl}$ in case group. The mean serum total bilirubin at 72 hours of life was $12.384+3.02 \mathrm{mg} / \mathrm{dl}$ in control group and $13.686+3.74 \mathrm{mg} / \mathrm{dl}$ in case group. There was no statistically significant difference in serum bilirubin and albumin levels in cord between male and female babies. These results matched with Taksande et al., [9] and Rostamiet al., studies [10].

The incidence of significant hyperbilirubinemia was $16.45 \%$ in control group and $21.6 \%$ in case group. The overall incidence of significant hyperbilirubinemia in our study was $18.4 \%$. This result correlates with Bernaldo AJN and Segre CA [11] and Nahar Z et al. [12] studies who reported an incidence of $15 \%$ and $15.5 \%$ respectively. In our study, we did not observe any statistically significant difference in developing significant hyperbilirubinemia between the two groups. This may be due to the small sample size.

By ROC analysis, the cutoff point for umbilical cord serum albumin for development of significant hyperbilirubinemia for the study population was $3.15 \mathrm{~g} / \mathrm{dl}$. This value predicts the development of significant hyperbilirubinemia with a sensitivity of $76.5 \%$, specificityof $78.7 \%$ and an accuracy of $77.6 \%$.

The area under the curve is 0.875 , which shows its high predictive value. This value was lower when compared to other authors. Venkatamurthy $\mathrm{M}$ et al[13] study reported that umbilical cord serum albumin level $>3.4 \mathrm{~g} / \mathrm{dl}$ to be safe as none of the babies with CSA more than this value developed hyperbilirubinemia in their study. Sandeep Kumar et al., [14] and Sahu S et al., [15] in their studies, reported an umbilical cord blood albumin level of $>3.4 \mathrm{~g} / \mathrm{dl}$ and $>3.3 \mathrm{~g} / \mathrm{dl}$ respectively, to be safe.

In control group, the cut-off value for umbilical cord blood albumin was $3.15 \mathrm{~g} / \mathrm{dl}$ with a sensitivity of $66.7 \%$, specificity of $73.9 \%$ and an accuracy of $70.9 \%$. In case group, a cut-off value of $3.15 \mathrm{~g} / \mathrm{dl}$ predicts the development of significant hyperbilirubinemia with a high sensitivity of $87.5 \%$, specificity of $86.2 \%$ and a high accuracy rate of $86.9 \%$. Thus, it was found that umbilical cord albumin has a high predictive value for significant hypebilirubinemia and the accuracy was higher in babies with $\mathrm{ABO}$ incompatibility compared to controls.

By ROC analysis, the cut-off value for umbilical cord serum total bilirubin for development of significant hyperbilirubinemia for the study population was $1.85 \mathrm{mg} / \mathrm{dl}$. This value predicts the development of significant hyperbilirubinemia with a sensitivity of $70.6 \%$, specificity of $82.7 \%$ and an accuracy of $76.7 \%$. The area under the curve was 0.876, which shows its high predictive value. Zietounet al[6] and Hamdi et al. [8] in their studies,reported a cut off value of $2.15 \mathrm{mg} / \mathrm{dl}$ and $2 \mathrm{mg} / \mathrm{dl}$ respectively. In control group, the cut-off value for umbilical cord serum total bilirubin was $1.75 \mathrm{mg} / \mathrm{dl}$ with a sensitivity of $88.9 \%$, specificity of $72 \%$ and an accuracy of $80.3 \%$. In case group, a cut-off value of $1.85 \mathrm{mg} / \mathrm{dl}$ predicts the development of significant hyperbilirubinemia with a sensitivity of $75 \%$, specificity of $79.3 \%$ and accuracy rate of $77.2 \%$. 
Editorial

Table-4: Comparison of cut-off values of umbilical cord bilirubin with various studies to predict neonatal hyperbilirubinemia.

\begin{tabular}{|c|c|c|c|}
\hline Sl. No. & Authors & Year & Results \\
\hline & & & Umbilical cord total serum bilirubin(predicts NNH) \\
\hline 1 & Our study & & $>1.85 \mathrm{mg} / \mathrm{dl}$ \\
\hline 2 & Bernaldo AJN and Segre CA [11] & 2004 & $>2 \mathrm{mg} / \mathrm{dl}$ \\
\hline 3 & Taksande A et al [9] & 2005 & $>2 \mathrm{mg} / \mathrm{dl}$ \\
\hline 4 & Hamdi et al [8] & 2012 & $>2 \mathrm{mg} / \mathrm{dl}$ \\
\hline 5 & Zeitoun et al [6] & 2013 & $>2.15 \mathrm{mg} / \mathrm{dl}$ in FT \\
& & & $>2.05 \mathrm{mg} / \mathrm{dl}$ in PT \\
\hline
\end{tabular}

\section{Conclusion}

Umbilical cord serum albumin and total bilirubin correlates well with the development of significant neonatal hyperbilirubinemia requiring treatment in the form of phototherapy with or without exchange transfusion in term ABO incompatible neonates. Further, these values help to categorize, neonates as either low or high risk for significant hyperbilirubinemia.

Hence it is recommended to routinely measure serum bilirubin and albumin levels in umbilical cord blood at birth in term $\mathrm{ABO}$ incompatible neonates. Babies with cord blood total bilirubin $>1.85 \mathrm{mg} / \mathrm{dl}$ and albumin $<3.15 \mathrm{~g} / \mathrm{d}$ l should be followed up closely to prevent the serious consequences of neonatal hyperbilirubinemia like kernicterus, while those babies with cord total bilirubin $<1.85 \mathrm{mg} / \mathrm{dl}$ and albumin $>3.15 \mathrm{~g} / \mathrm{dl}$ can be safely discharged early to minimize unnecessary prolongation of hospitalization.

\section{What this study adds?}

In $\mathrm{ABO}$ incompatibility, umbilical cord blood bilirubin and albumin has good correlation with subsequent development of significant hyperbilirubinemia.

Contributors: JAN: Patient recruitment, data collection and manuscript writing. SP: Finalized the protocol, supervised the study and reviewed the manuscript. He will serve as guarantor of the study.

Funding: Nil, Conflict of interest: None initiated, Perission from IRB: Yes

\footnotetext{
Abbreviations Excellence

AAP - American Academy of Pediatrics

ROC - Receiver Operator Characteristic

$\mathrm{Sr}-\mathrm{Serum}$

CSA - Cord Serum Albumin
}

NICE - National Institute of Health and Clinical

\section{References}

1. Christensen RD, Yaish HM, Nussenzveig RH, Reading NS, Agarwal AM, Eggert LD, Prchal JT. Acute kernicterus in a neonate with $\mathrm{O} / \mathrm{B}$ blood group incompatibility and a mutation in SLC4A1. Pediatrics. 2013 Aug;132(2):e531-4. doi: 10.1542/peds.2012-3799. Epub 2013 Jul 22.

2. Serious Reportable Events in Healthcare- 2011 update: a consensus report. Washington DC: National Quality Forums;2011.

3. Radmacher P, Massey C, Adamkin D. Hidden morbidity with "successful" early discharge. J Perinatol. 2002 Jan; 22 (1): 15-20. DOI: 10. 1038/sj. jp.721 0586 .

4. Kiely M, Drum MA, Kessel W. Early discharge. Risks, benefits, and who decides. Clin Perinatol. 1998 Sep; 25 (3):539-53, vii-viii.

5. American Academy of Pediatrics Subcommittee on Hyperbilirubinemia.Management of hyperbilirubinemia in the newborn infant 35 or moreweeks of gestation. Pediatrics. 2004 Jul;114(1):297-316.

6. Zeitoun AA, Elhagrasy HF, Abdelsatal DM. Predictive value of umbilical cord bloodbilirubin in neonatal hyperbilirubinemia. Egyptian Pediatric Association Gazette. 2013 Jan; 61 (1): 23-30.doi:10. 1016/j. epag.2013.04.006.

7. Aljabri MM, Khoogh FF, Alsolimani SA, Saleh IH, Alshehri IA, Alshehri MM. Effectiveness of cord blood albumin as a predictor of neonatal jaundice. Int $\mathrm{J}$ Health Care Sci. 2015Oct;3(2):340-2.

8. Hamdi N, Elgayar A, Salah MH. Cord blood bilirubin as a predictor of neonatal hyperbilirubinemia. Med J Cairo Univ. 2012 Jun; 80(2):31-6. 


\section{Editorial}

9. Taksande A, Vilheker K, Jain M, Zade P, Atkari S, Verkey S. Predictionof the development of neonatal hyperbilirubinemia by increased umbilical cord blood bilirubin. Curr Pediatr Res. 2005Jul; 9 (1\&2):5-9.

10. Rostami N, Mehrabi Y, Asadzadeh F. Identifying the newborns at risk for developing significant hyperbilirubinemia by measuring cord bilirubin levels. J Arab Neonatal Forum. 2005;2:81-5.

11. Bernaldo AJ, Segre CA. Bilirubindosage in cord blood: could it predictneonatal hyperbilirubinemia? Sao Paulo Med J. 2004 May 6;122(3): 99-103. Epub 2004 Sep 16.

12. Nahar Z, Shahidulla, Mannan A, Dev SK, Mitra U, Sellimuzaman SM. The value of umbilical cord blood bilirubin measurement in predicting the development of significant hyperbilirubinemia in healthy newborn.
Bangladesh J Child Health.2010 Aug;33(2):50-4.doi:10. 3329/ bjch.v33i2.5677.

13. Venkatamurthy M, Murali SM, Mamathy S. A comparison study; cord serum albumin is compared with cord serum bilirubin as a risk indicator in predicting neonatal jaundice. Journal of Evolution of Medical and Dental Sciences. 2014Apr;4017-22.doi:10. 14260/jemds/2014/2393

14. Sandeepkumar, Manjunath GA, Ajay J, Reddy S. Low cord serum albumin is a risk indicatorin predicting neonatal jaundice. IOSR Journal of medical and dental sciences. 2016 Oct; 15 (10): 76-8.doi: 10. 9790/ 08531510017678 .

15. Sahu S, Abraham R, John J, Mathew MAA, George A. Cord blood albumin as a predictor of neonatal jaundice. Int J Biol Med Res. 2011; 2 (1): 436-8.

\section{How to cite this article?}

Janaki A.N, Selvakumar P. Predictive value of umbilical cord blood bilirubin and albumin for significant hyperbilirubinemia in ABO incompatibility. Int J Pediatr Res. 2018;5(1):24-30. doi:10.17511/ijpr.2018.i01.06. 